\title{
ESTUDIOS
}




\section{LA CREAción de UN ESPAcio FeUdAL: GL VALLE dE VALDIVIELSO}

por

\section{INAKAKI MARTÍN VISO}

Facultad de Geografía e Historia.

Universidad de Salamanca.

RESUMAN: En el norte de Cantabria y de Castilla el feudalismo se organizó sobre las "comunidades de vallew, un espacio primitivo cuya estructura se mantuvo hasta la Edad Moderna. El valle es un espacio marginal, poco jerarquizado, que mantuvo el modelo aldeano bajo el sistema feudal.

Palabras Clave. Castilla, feudalismo, aldeas y sociedades gentilicias, siglos viII-xII.

ABSTRACT: In the North of Cantabria and Castile, Feudalism was organized in "walley communities", an primitive space which structure was mantained until the 18th. century. The "walley" is a marginal space, scarcerly hierarchical, which within the feudal system mantain peasant model.

KeY wORDS: Castile, Feudalism, Peasant community, 8th-12th centuries.

Una de las propuestas más fructíferas y polémicas realizadas desde la historiografía española respecto a la comprensión del periodo medieval es la denominada "organización social del espacio", cuyo principal promotor es J.A. García de Cortázar ${ }^{2}$. Dentro de esta línea de trabajo, cuya pretensión es regis-

\footnotetext{
1 Este trabajo se ha realizado dentró del proyecto de investigación PS93-0066.

Las abreviaturas utilizadas son las siguientes: Archivo Histórico Nacional $=A H N$; ÁLAMO, Juan del, Colección diplomática de San Salvador de Oña, Madrid, 1950, 2 vols. =ÁLAMO; II Jornadas Burgalesas de Historia. Burgos en la Alta Edad Media, Burgos, 199]=BAEM; HI Jornadas Burgalesas de Historia. Burgos en la Plena Edad Media, Burgos, $1994=B P E M$; MARTínez Díez, Gonzalo, El libro Becerro de las Behetrías. Estudio y texto crítico, León, 1981, 3 vols. $=B E C E R R O$ DE LAS BEHETRIAS; OCEJA GONZALO, Isabel, Documentación del monasterio de Oña (10321350), Burgos, 1983-1986, 5 vols. $=O C E J A$

2 Los dos trabajos fundamentales en los que plantea tal propuesta y la desarrolla en términos más generales son «Espacio, sociedad y organización medieyales en nuestra tradición historiográfica», en
} 
trar y analizar los cambios en el espacio provocados por la sociedad feudal, se pretende definir con claridad las unidades que componen la organización social del espacio; entre ellas, se encuentra el "valle" gentilicio o "comunidad de valles, que ha sido objeto de estudio en el ámbito norteño peninsular ${ }^{3}$. Representa una aportación evidente en la explicación de los procesos de feudalización del norte peninsular y de las áreas periféricas de los reinos cristianos. No se debe obviar el hecho de que fueron antropologos, como Julio Caro Baroja, quienes primero introdujeron la realidad de los «valles" para estudiar los comportamientos sociales de los pueblos de la Cornisa Cantábrica ${ }^{4}$.

Se trata de una unidad espacial de origen gentilicio cuya característica principal sería la percepción supralocal, minicomarcal, del espacio que se entiende como «un ámbito de aprovechamiento económico reconocido a un grupo de parentescon 5 . No responde necesariamente a la morfología física de un valle - aunque en general así sucede - sino que puede ser un espacio cualquiera que se amolde a determinados rasgos de tipo económico y social. Una de esas características era la pervivencia de costumbres derivadas de la ocupación gentilicia inscritas dentro de un aprovechamiento ganadero seminómada. Junto con esta actividad ganadera preponderante, convive una agricultura de barbechos prolongados con una función subsidiaria. En cuanto a la organización social, la autoridad recairía sobre un jefe, el cual, junto a otros jefes de segmentos similares y dentro de un grupo más amplio, representa a su segmento en un consejo con competencias sobre el territorio ocupado por todo el conjunto de tribus o familias. Los vínculos de parentesco, por otra parte, son los que dotan de coherencia a este organigrama social que unifica espacio geografico y unidad socio-política ${ }^{6}$.

Organización social del espacio en la España medieval. La Corona de Castilla en los siglos vill a xv, Madrid, 1985, págs. 1 1-42, y «Organización social del espacio: propuestas de reflexión y análisis histórico de sus unidades en la España medieval»: Studia Historica. Historia Medieval VI (1988) págs. 195-236.

3 Vid AchúcARRo, Mercedes, «La tierra de Gujpúzcoa y sus «valles»: su incorporación al reino de Castillas: En la España Medieval. Estudios dedicados al profesor D. Ángel Ferrari Núñez, Madrid, vol. I, 1984, págs. 13-46; GARCla DE CORTAZAR, José Angel «Poblamiento y organización social del espacio vasco en la Edad Median: Congreso de Historia de Euskal Herria, San Sebastián, vol. II, 1987, págs. 421-443; ORTEga VALCÁRCEL, José, La Cantabria rural. Sobre la Montaña, Santander, 1987; Barrena Osoro, Elena, La formación histórica de Guipúzcoa, San Sebastián, 1989; Diez Herrera, Carmen, La formación de la sociedad feudal en Cantabria. La organización del territorio en los siglos IX al XIV, Santander, 1990; Imizcoz BEÚNZA, José M.", "Comunidad de valle y feudalismo en el norte de la Península: algunas preguntas desde el valle de Baztán»: Señorío y feudalismo en la Península lbérica (siglos X11-X1X), Zaragoza , vol. JII, 1993, págs. 69-86.

4 Buena prueba de ello es la centralidad del «valle» como elemento de la administración territorial y de la organización social en Navarra y Álava. Vid. Caro Baroja, Julio, «Álava en la llamada Reja de San Millánn: Caro Baroja, Julio (dir.), Historia General del País Vasco, San Sebastián, vol. III, 1983, pág. 125.

5 García de CoRTȦzar, José Ángel, La sociedad nural en la España medieval, Madrid, 1988, pág. 14.

${ }_{6}$ En este sentido, se adecúa perfectamente a las propuestas acerca de las organizaciones segmentarias características de determinados sistemas tribales. Vid. SAHLINS, Marshall D., Las sociedades tribales, Barcelona, 1984, págs. 30 y ss.

Hispania, LVII/2, núm. 196 (\$997) 679-707 
El poblamiento de los "valles" se basa en pequeñas aldeas, barrios o barriadas y un número dispar de caseríos dispersos; en la mayor parte de las veces, la agrupación de casas no es más que una contigüidad de las viviendas. Los barrios se disponen a una distancia de dos o tres kilómetros entre sí, pudiendo formar un microconcejo con competencias sobre cuestiones complementarias relacionadas con la sociabilidad a su escala ${ }^{7}$. De cualquier forma, parece un tópico afirmar dentro de esta propuesta la anterioridad de la realidad del "valle" respecto de la aldea.

La importancia de estos "valles» deriva de su persistencia; se defiende que, en buena parte del norte peninsular, dichas "comunidades de valle" o bien resisten al feudalismo, manteniendo en rasgos generales su estructura, o bien su adaptación al sistema feudal conlleva una cierta peculiaridad social y económica.

Esta propuesta ha sido muy fecunda, ya que permite analizar la actividad de los grupos gentilicios, cuya desintegración es postulada mayoritariamente por los historiadores como origen del feudalismo ibérico - salvo la excepción de la Marca Hispánica--, si bien la falta de datos convierte a estas sociedades gentilicias en organismos difíciles de aprehender. Aunque su estudio se ha centrado en la Cornisa Cantábrica, lo cierto es que se han hecho reflexiones a partir de este planteamiento en otras regiones. Un estudio reciente señala como hipótesis que las zonas de contacto entre la submeseta norte y la Cordillera Cantábrica (desde Astorga hasta Amaya), áreas con un marcado carácter "periférico", se organizan en forma de "comunidades de valle" ajenas a los poderes meseteños durante el largo período que va de la romanidad tardía a los principios del proceso de feudalización ${ }^{8}$. También se han encontrado supuestos vestigios de una primitiva "comunidad de valle» fosilizada en el siglo XV en una subcomarca muy aislada del Bierzo: el valle de Fornela y Los Ancares ". Igualmente, yo mismo he defendido la existencia de un sistema similar a las "comunidades de valle» en Sanabria, en el oeste de Zamora ${ }^{10}$. El territorio correspondiente a la actual provincia de Burgos no ha sido ajeno a esta preocupación, máxime si tenemos en cuenta que su zona septentrional constituye un espacio complejo y con una estrecha relación con áreas de "valles" como Cantabria y Vizcaya. La toponimia actual ha sido utilizada para afirmar la existencia de una vieja realidad de «valle» transformada; la aparición del nombre de un espacio en la forma de topónimo (Merindad de Montija, Sargentes de la Lora) o en el nombre y la forma (Valle de Mena, Valle de Manzanedo) serían vestigios de dicha realidad ${ }^{11}$. El análisis de la documen-

7 Vid. Garcia de Cortázar, José Ȧngel, «Organización social del espacio: propuestas de reflexión...», págs. 220-221; Diez HerRera, Carmen, op. cit., págs. 17, 25 y 51.

y GUTtÉRREz GonzÁLEZ, José Avelino, Fortificaciones y feudalismo en el origen y formación del reino leonés (siglos :x-XIII), Valladolid, 1995, págs. 95-96.

9 Rodriguez González, M. Carmen, Economía y sociedad en el Bierzo en el siglo xv. San Andrés de Espinareda, Santiago, 1992, págs. 62-65 y 287-289.

10 Martin Viso, Iñaki, «La feudalización del valle de Sanabria»: Studia Historica. Historia Medieval XI (1993), págs. 35-55.

"Vid. Garcia DE CORTȦZAR, José Ángel, «Organización social del espacio burgalés en ta Alta Edad Medias: $B A E M$, pág. 61.

Hispania, LVIU/2, núm. 196 (1997) 679-707 
tación medieval nos proporciona al respecto una paradoja: a la homogeneidad de la denominación del espacio administrativo o político, se oponen las formas locales de organización del espacio castellano, donde permanecen como elementos básicos los «valles" ${ }^{2}$. Sin embargo, los argumentos permanecen en un plano teórico ante la escasez de trabajos de campo que determinen la validez o no de esta hipótesis de trabajo. Se precisa un estudio empírico que permita ratificar o cambiar ese paradigma que lentamente se impone en la explicación del periodo altomedieval de la zona septentrional de Burgos, la más vieja Castilla. He escogido para ello un típico valle de las Merindades de Castilla ya mencionado como posible "valle" gentilicio: Valdivielso ${ }^{13}$.

El valle de Valdivielso se localiza al norte de la actual provincia de Burgos, en la zona meridional de las Merindades de Castilla la Vieja, de las que forma parte. Agrupa a catorce núcleos de población que se extienden por una superficie de unos $150 \mathrm{Kms} .{ }^{2}$ formada por una depresión sinclinal de personalidad muy acusada. Por el norte y con dirección Noroeste-Sudeste se encuentra el anticlinal de Tesla (Sierra de Tesla o la Tesla), que es la continuación del anticlinal de Leva, abruptamente cortado por la "cluse" de Los Hocinos que forma el Ebro; la Tesla aparece como un pliegue bastante regular y simétrico con alturas máximas superiores a los 1.200 metros, que separa el sinclinal de Villarcayo-Tobalina y el de Valdivielso. Al sur y al oeste, se levantan los altos de Dobro, la plataforma sobre la que se asienta la comarca de la Lora, con desniveles de 400 metros sobre el valle. Este se encuentra regado por el Ebro, que proviene del cercano valle de Manzanedo, y que articula el espacio del sinclinal. La imagen es la de un pequeño valle cuyas características principales son la escasez de desniveles y la regularidad geomorfológica, con el Ebro como eje, así como una climatología más templada que en las zonas circundantes ${ }^{14}$.

La nitidez del espacio ocupado por el valle ha definido una personalidad geográfica muy acusada percibida ya en la Edad Media. Así, para el año 967 . poseemos una información sobre un "Valle de Vielso" 15; en los falsos "votos de San Millán», que reflejan la visión que en el siglo XII se tenía de la organi-

12 Aparecen así Valderejo, Valdegovía, Valle de Petrapidonia, Valdivielso, Valle de Zamanzas, Valderredible y valle de Campoo en la parte septentrional, aunque hay otros en el sur. Vid. ORTEGA VALCÁRCEL, José, «Geografia histórica de Burgos altomedieval»: BAEM, págs, 185-186. Pero, este autor define al valle como una unidad territorial que corresponde a un grupo de aldeas cuyos término engloba y a las que otorga cohesión social; ocurriría así en el norte de Burgos, desde la Liébana hasta los valles alaveses. Vid. «Geografia histórica de un espacio feudal: la región de Burgos en la Edad Media»: BPEM, págs. 18-19.

13 El valle de Valdivielso fue analizado en mi memoria de licenciatura inédita El poblamiento en el Norte de Burgos: la Lora y Valdivielso (siglos IX-Xin), Salamanca, 1995.

14 Para los aspectos geográficos es de especial interés el Jibro de MANERo, Fernando, Valdivielso, una comarca de la montaña de Burgos, Valladolid, 1972. También son interesantes las apreciaciones de ORTEGA VAlCÁRCEL, José, La transformación de un espacio rural. Las Montañas de Burgos, Valladolid, 1974.

is ALAMO, vol. I, doc. 5 (967): «In Valle de Vielso, cella Sancti Andre cum integritate», diferenciándolo de Valderredible y Castilla Vieja. De todas formas, este documento, como la mayoria de

Hisponia, LVII/2, nủm. 196 (1997) 679-707 
zación territorial de la Castilla altomedieval, aparece: "Valle de Vielso, cum omnibus suis villis ex utraque parte» ${ }^{16}$. De cualquier forma, existen numerosos ejemplos más en la documentación escrita de los siglos XII al XIV, que demuestran la vigencia de un espacio de valle claramente diferenciado, llegando incluso a la creación de un genitivo que se suma al nombre de determinados lugares ${ }^{17} \mathrm{y}$ al de algunos personajes ${ }^{18}$.

La clara delimitación geográfica, cuya percepción es más evidente por el aislamiento del espacio físico, constituye un factor clave en la acentuada personalidad de la comarca. Sin embargo, no hay noticias directas sobre ningún tipo de organización territorial que tuviera por base Valdivielso durante la Edad Media. Hay que esperar a finales del xV y, sobre todo, a la época moderna, para encontrarnos con una Merindad de Valdivielso adscrita al Ayuntamiento General de las Merindades de Castilla la Vieja. Durante el Antiguo Régimen, se desarrolla un espacio jurisdiccional propio dotado de unos órganos administrativos específicos, los cuales incluyen juntas y cargos electivos, si bien toda esta actividad se inscribe en un marco más amplio (las Merindades de Castilla la Vieja) que limita las atribuciones y autonomía de la Merindad de Valdivielso a un nivel comarcal ${ }^{19}$. Esta tardía identificación con un espacio territorial bien articulado supone una aparente paradoja frente a su definida personalidad en otros ámbitos; es esta carencia uno de los aspectos más llamativos que no pueden obviarse a la hora de estudiar el valle.

la época, presenta muchos problemas en cuanto a su veracidad. La crítica textual puede leerse en PÉREZ DE URbel, Justo, Historia del Condado de Castilla, vol. III, Madrid, 1945, doc. 371. La fiabilidad de este testimonio es puesta en duda por LECANDA EsTEBAN, José Ángel, «El poblamiento y la organización del territorio septentrional de Burgos en el siglo xl»: BPEM, págs. 639 y 644.

16 Ubieto ARTETA, Antonio, Cartulario de San Millán de la Cogolla (759-1076), Valencia, 1976, doc. 22, que aparece fechado en el 934, pero que el editor del documento considera que es una falsificación de mediados del XIl, entre 1140 y 1143.

17 Actualmente el apelativo «de Valdivielso» aparece en las localidades de Arroyo de Valdjvielso, Herrera de Valdivielso (en la comarca de Caderechas), Hoz de Valdivielso, Población de Valdivielso, Quintana de Valdivielso, Santa Olalla de Valdivielso y Toba de Valdivielso. En la Edad Media, se aplicaba igualmente este apelativo, como se puede ver en $O C E J A$, vol. I, doc. 107 (1209, aprox.), donde aparecen: Fahedo de Valdeviesso (Ahedo de Butrón), Sancto Claudio de Valdeviesso (en Valdenoceda) y Arenas de Valdeviesso.

18 Tal es el caso de la familia Valdivielso, asentada en Burgos y que desempeñó cargos en la administración territorial del espacio burgalés a finales del xII y principios del XIV. Vid. CASADO, Hilario, Señores, mercaderes y campesinos. La comarca de Burgos a fines de la Edad Media, Valladolid, 1987, pág. 450.

19 Sobre las Merindades de Castilla la Vieja y su organización juridica en la Edad Moderna, vid. GARCia Y SÁINZ DE BARANDA, Julián, Apuntes históricos sobre las merindades antiguas de Castilla, Burgos, 1952 y SANCHEZ Domingo, Rafael, Las merindades de Castilla Vieja y su Junta General, Burgos, 1994, y específicamente para Valdivielso HUIDOBRo SERNA, Luciano y García Y SÁINZ DE BARANDA, Julián, Apuntes descriptivos, históricos y arqueológicos de la Merindad de Valdivielso, Burgos, 1930. Curiosamente, sucede de forma idéntica en un ejemplo reciente de «comunidad de valle» como es el Baztán; vid. Imlzcoz BeunzA, Jose M. ${ }^{2}$, op. cit., págs. 73-74. 
En cualquier caso, lo que importa subrayar aquí es el incontestable parecido de Valdivielso con otros valles de la vertiente cantábrica que han dado pie a la propuesta de las "comunidades de valle». Se trata, por tanto, de un territorio propicio a ser utilizado como campo de trabajo en el que desarrollar la hipótesis antedicha. Pero ¿realmente es así? Mi propósito ahora es observar los grandes rasgos de la evolución histórica de Valdivielso en la Edad Media. Para ello, es necesario remontarnos hasta la época anterior a la dominación romana a fin de conocer algunas de las claves de dicha evolución.

El espacio de Valdivielso se encuentra adscrito historicamente al territorio ocupado por los cántabros, y más concretamente por los cántabros occidentales o morecanos ${ }^{20}$. La pertenencia a uno u otro pueblo no es una cuestión simplemente erudita; es posible aceptar la idea expresada por J. J. García González de que cada etnia había adecuado su asentamiento a nichos de personalidad ecológica bien establecida. Así, el territorio de los cántabros occidentales era una zona de aprovechamiento fundamentalmente agropastoril perfectamente adaptada a las posibilidades y necesidades de estas gentes ${ }^{21}$. Sin embargo, Valdivielso es una zona limítrofe con el territorio autrigón, pueblo con actividades más vinculadas a la agricultura, si bien es cierto que la territorialidad no estaba claramente definida entre estos pueblos ${ }^{22}$. En cualquier caso, no parece que el valle ocupara una función central en el territorio cántabro, sino que, de acuerdo con una territorialidad más tenue, era aprovechado por dicho pueblo de forma marginal, al no ajustarse a sus necesidades ni a la de los autrigones, en especial por las difíciles comunicaciones con la comarca de la Bureba.

Las guerras cántabras precipitaron el fin de la autonomía que gozaban los pueblos de la Cornisa Cantábrica. La presencia romana será continua y prolongada en toda la zona cántabra, aunque no supuso una labor eficaz de romanización a nivel de toda la región, siempre y cuando defendamos ésta como la expansión de la vida urbana antigua, que incluiría: la propiedad privada, el esclavismo, el intercambio de mercancías en una economía monetaria, la aceptación del modelo de la familia patriarcal y la subsecuente desintegración de la vida tribal indígena ${ }^{23}$. Es bien conocido el hecho de que la penetración romana fue muy escasa en el norte de Burgos, reducida a

20 Vid. SERRANo, Luciano, El obispado de Burgos y la Castilla primitiva desde el siglo $\mathrm{v}$ al $\mathrm{xII}$, vol. 1, Madrid, 1935, págs. 2-3, Garcia Y SÁINZ DE BARANDA, Julián, Apuntes históricos sobre las merindades..., pág. 44. Más recientemente, han defendido la adscripción cántabra de Valdivielso Caro Baroja, Julio, Los pueblos del norte de la Península lbérica, San Sebastián, 1973, pág. 44, SolanA SÁINZ, José M. ${ }^{,}$, «Los cántabros: territorio y costumbres»: Hispania Antiqua xvi (1992), pág. 13 y. Garcia GonZÁLEZ, Juan José, «Fronteras y fortificaciones en territorio burgalés en la transición de la Antigüedad a la Edad Median: Cuadernos Burgaleses de Historia Medieval 2 (1995), pág. 20.

${ }_{21}$ García GonzAlez, Juan José, «Fironteras y fortificaciones...», pág. 22.

22 Ibid., pág. 25.

23 'BARBERo, Abilio y VIGIL, Marcelo, Sobre los orígenes sociales de la Reconquista, Barcelona, 1974 , pág. 145.

Hispania, LVII/2, nưm. 196 (1997) 679-707 
determinados puntos concretos en los que se puede observar una efectiva presencia y actividad. Los vestigios que nos proporciona el registro arqueológico reflejan que Valdivielso participa de ese modelo. Unicamente en Valherrnosa se han encontrado restos de "terra sigillata» y cerámica común romana de factura tosca, así como columbarios; algunos autores han querido ver en estos datos indicios suficientes para identificar el yacimiento con una villa bajoimperial ${ }^{24}$. No soy de la misma opinión, ya que los datos existentes no permiten ir más allá de la simple adscripción del yacimiento a la época romana. Pero, aunque fuera una "villa", no sería testimonio suficiente de una romanización eficaz, puesto que no hay más vestigios arqueológicos en todo el valle. En consecuencia, cabe afirmar que Valdivielso no estuvo sometido a una presion colonizadora por parte de los romanos.

La crisis del siglo III supuso la recuperación de la autonomía de las gentes al norte del Ebro; las antiguas formas de organización de la sociedad y del espacio, levemente modificadas por la dominación romana, se reactivan y vuelven a protagonizar la articulación social de estas gentes. No es difícil imaginar que hubo modificaciones, pero éstas se debieron básicamente a la propia dinámica de estos pueblos. El último cuarto del siglo vi fue el momento en el que el reino visigodo se hizo con el control del área septentrional de Burgos. No obstante, su dominio fue, al igual que el de los romanos, muy puntual y desigual, conformándose con el control nominal de la región. En nuestro valle, no existe ningún vestigio ni noticia documental fiable que hable de la presencia visigoda. Tal situación adquiere una significación importante si se advierte de que a pocos kilómetros, en zona anteriormente autrigona, se encuentra el principal foco visigodo de la región en torno a Mijangos y Cillaperlata ${ }^{25}$; no era sólo una razón de difjcultad geográfica la que explicaba la diferencia entre ambas zonas en cuanto a la presencia visigoda -terminología que, por otro lado, debe ser revisada y depurada en cuanto a su sentido étnico-, sino que interviene claramente un proceso histórico bien diferenciado por parte de dos pueblos con gradientes de evolución social diversos.

El valle se encontraba, sin embargo, habitado. Las pruebas arqueológicas no son abundantes; poseemos datos acerca de una pequeña necrópolis con sepulturas excavadas en roca en Arroyo de Valdivielso, en las llamadas "Cuevas de

24 Vid. Bohigas Roldan, Ramón, Campillo Cueva, Jacinto y Churruca Gutiérrez, José Ángel, «Carta arqueológica de la provincia de Burgos. Partidos judiciales de Sedano y Villarcayo»: Kobie 14 (1984), pág. 55; Garcia GonZÁlez, Juan José, «Fronteras y fortificaciones...», pág. 37 (mapa 2).

${ }_{25}$ Vid. LORING Garcia, M. Isabel, Cantabria en la Alta Edad Media: organización eclesiás tica y relaciones sociales, Madrid, 1987, pág. 129 y ss.; ANDRIo, Josefina y LoYOLA, Esther, El conjunto arqueológico del monasterio de San Juan de la Hoz de Cillaperlata (Burgos), Miranda de Ebro, 1992; Garcia González, Juan José, «Iglesia y religiosidad en Burgos en la Plena Edad Media»: BPEM, págs. 312-313 (notas 16 y 17); LeCANDA ESTEBAN, José Ángel, «El epígrafe consacratorio de Santa María de Mijangos (Burgos). Aportaciones para su estudion: Letras de Deusto 65-24 (1994), págs. 173-195. 
los Moros" ${ }^{26}$, que corresponde con un tipo de inhumación que puede registrarse desde el siglo $\mathrm{VII}$ hasta el $\mathrm{x}$ en la submeseta norte ${ }^{27}$. Los indicios son escasos, pero hay que señalar que la labor arqueológica en Valdivielso está aún por hacer. La evolución posterior del poblamiento permite en cambio formular como hipótesis la presencia humana en el valle durante esta época. Es muy posible que la práctica del nomadismo, relacionada con una actividad ganadera predominante, en consonancia con los hábitos económicos de muchos de estos pueblos, influyera en la configuración de un hábitat poco estable. Son las propias contradicciones del sistema indigena las que favorecen una creciente sedentarización que aprovecha los asentamientos anteriores, convirtiéndolos en estables, al mismo tiempo que se generan otros "ex nihilo" ${ }^{28}$. Por lo tanto, parto de la consideración de Valdivielso como una zona básicamente de pastos en la que se va imponiendo un hábitat de tipo aldeano de forma paulatina; es decir, un área donde se encontraban los pastos necesarios para una economía preponderantemente ganadera (aunque existen otras actividades económicas subsidiarias) que utilizaba un sistema trashumante. Frente a otras zonas cántabras en las que el sistema castral estructura el espacio, como sucede en la Lora o en el valle de Manzanedo, hay muy pocos restos de recintos castrales en el valle. En Condado, en Monte Sagrero, poseemos noticias de un posible castro, probablemente de la Edad del Hierro ${ }^{29}$; en Valdenoceda, en torno a la ermita de San Cristóbal, enclavada en lo alto del monte del mismo nombre, hay restos de un despoblado que se ha identificado con Celada, lugar que aparece "yermon en el "Becerro de las Behetrías» ${ }^{30}$, si bien su identificación como castro es más que dudosa. En ambos casos nos encontramos con serias dificultades para su adscripción castral; esta debilidad o inexistencia de las estructuras castrales parece reforzar el sentido de que Valdivielso era más una zona de aprovechamiento ganadero y de ocupación temporal o inestable, frente a las áreas de asentamiento más fijas.

Desde el siglo $\mathrm{x}$, y con mayor seguridad en el XI, Valdivielso aparece en la documentación escrita. El primer testimonio se refiere a la creación de San Pedro de Tejada en el siglo IX, cuya fundación es muestra de la tradición pac-

26 Bohigas Roldàn, Ramón, Campillo Cueva, Jacinto y Churruca Pérez, José Ángel, op. cil., pág. 69; MONREAL JIMENO, Luis Alberto, Eremitorios rupestres altomedievales (El Alto valle del Ebro), Bilbao, 1989, pág. 68.

27 López Quiroga, Jorge y Rodríguez Lovel Le, Mónica, «Poblamiento rural en el noroeste de la Peninsula Ibérica (siglos $\mathrm{V}$-XI): una introducción al estudio del poblamiento rural entre la Antigüedad tardía y la Alta Edad Media en Galicia a través de un análisis micro-regional»: Boletín de Arqueología Medieval 7 (1993), pág. 27.

28 Un ejemplo significativo se encuentra en la Lora, como señalé en mi artículo «Poblamiento y sociedad en la transición al feudalismo en Castilla: castros y aldeas en la Lora burgalesan: Studia Historica. Historia Medieyal 12 (1995), pp. 3-45.

29 Bohigas Roldán, Ramón, Campillo Cueva Jacinto y Churruca Pérez, José Ángel, op. cit., pág. 55.

${ }_{30}$ BECERRO DE LAS BEHETRfAS, vol. Il, pág. 539.

Hispania, LVIJ/2, núm, 196 (1997) 679-707 
tual monástica de la Alta Edad Media ${ }^{31}$. Según las copias de Yepes y Argaiz, 33 personas suscriben el pacto, apareciendo un listado de iglesias parroquiales de las que reciben diezmos, incluyendo el monasterio de San Andrés de Población ${ }^{32}$. Pero los autores de esas noticias no ofrecen suficientes garantías de veracidad; la aparición de diezmos bien estructurados en torno a parroquias así como la existencia de San Andrés de Población en dicha época y unido a San Pedro de Tejada - mientras en la donación fundacional de San Salvador de Oña se dan por separado ambos monasterios o "ecclesias"-parecen ser, como mínimo, interpolaciones muy posteriores. A pesar de todas las dudas que se plantean, se puede aceptar un fondo de verdad en tanto que San Pedro de Tejada pudo ser fruto de la actividad de comunidades preexistentes, algo que se aceptaba todavía en el $\mathrm{xrx}^{33}$.

Si dejamos aparte la noticia que teneríos sobre una «cella» de San Andrés, probablemente San Andrés de Población, en el siglo $x$, que he reseñado en la nota 14, la donación fundacional de San Salvador de Oña se convierte en el testimonio más importante de esta época sobre Valdivielso. El conde Sancho concede al nuevo cenobio diversos bienes en Valdivielso, concretamente en Condado, Población, San Pedro de Tejada, Santa Olalla, Quecedo, Valdenoceda y Valdeviña, así como otras iglesias no localizadas; dicha donación incluye centros religiosos, "casatos" y determinadas localidades "cum integritate» ${ }^{34}$. Es evidente que se han creado una serie de núcleos de población,

31 Vid. Pérez de Urbel, Justo, op. cit., vol. III, doc. 26 ( $₫ 850-866 ?$ ): «Pactum fecimus Deo et tibi pater nostro Rodanio abbate, et fillium, et secundum edictum Apostolorum et regula monasterio sicut sancta patrum precedentium sanxit auctoritas uno in cenobio...». Aunque cabe dudar de la fiabilidad del documento, el hecho de que se conserve en forma de pacto le concede al menos una cierto grado de veracidad.

32 Yepes, Antonio de, Crónica General de la Orden de San Benito, Valladolid, 1615, V, fol. 331 ; ARgalz, Gregorio, La Soledad Laureada por San Benito y sus hijos en las iglesias de España, Madrid, 1675, págs. 423-424. Los đatos son aceptados totalmente como ciertos por CoRULLÓN PARE$D E S$, lsabel, «Monacato y organización eclesiástica en la Castiila altomedieval»: $B A E M$, págs. 596598 y MANERo, Fernando, op. cit., págs. 56-57.

33 AHN, Clero, San Salvador de Oña, leg. 1308, «Ttaslado de títulos» (año 1832), fols. 110v111 r.: «Este San Pedro de Tejada fue monasterio mucho más antiguo que el de Oña (...) fue fundado y dotado por clérigos particulares que, reunidos en comunidad y eligiendo su superior, profesaban en él la vida religiosa bajo la regla de San Benito. Y desde él, administraban la cura de almas a los habitantes del valle de Valdivielso y a las familias christianas que, huyendo de los moros, venían sucesivamente y fijaban su residencia allí, sirviéndoles como de ayudas de parroquias varias hermitas que edificaron al intento a varias distancias y a donde se dice Valdenoceda, la Quintana, la Alminé, Santa Olalla, Toba, Condado, Panizares, Hoz, Valdehermosa, Arroyo, Población y Quecedo..."

34 ÁLAMO, vol. I, doc. 8 (1011-II-12): «Villa Cometato cum ecclesia Beate Marie, ab omni integritate. Villanova, cum integritate. Sancti Andree in Populatione curn integritate. Sancti Petri de Teggada cum integritate. Ecclesia Sancti Facundi cum integritate. Ecclesia Sancti Emeterii cum integritate. Ecclesia Sancti Romani cum integritate. Ecclesia Sancte Eulalie cum integritate. In Keçedo ecclesia Sancti Forencii cum integritate. In Valle de Noçeda, Ill casatos. In Valle de Vinea ecclesia Sancte Marie cum integritate et II casatos».

Hispunia, LVIJ/2, núm. 196 (1997) 679-707 
en los que la iglesia local cumple un papel de gran importancia. Pero no tienen un origen reciente, ya que algunos de ellos presentan rasgos de una territorialización efectiva del espacio circundante únicamente explicable por una larga existencia como tales ${ }^{35}$. Aún así, y como tendremos ocasión de analizar más adelante, la importancia de los centros monásticos o religiosos será determinante en muchos casos.

La presencia en el XI de una red de asentamientos bien establecida en Valdivielso es de todas formas incuestionable. La secuencia temporal de aparición documental de los núcleos de población es la siguiente: Condado, Población, Quecedo, Santa Olalla, Valdenoceda y Valdeviña en el $1011^{36}$, Arenas de Valdivielso en el $1044{ }^{37}$, Valhermosa en $1102{ }^{38}$, Quintana hacia el $1180^{39}$, Tejada en el $1193^{40}$, Hoz en $1199^{41}$, Arroyo en $1200^{42}$, Puente en $1202^{43}$, Tartalés de los Montes y Toba en $1203^{44}$ y Panizares en $1248^{45}$. Por tanto, para el siglo XI, poseemos noticias documentales para casi la mitad de los asentamientos, lo que es indicativo de que la red estaba ya asentada. Si se contempla el mapa, se observa como la zona más occidental del valle, la de mejor terrazgo, es la primera en ocuparse, frente al área oriental, donde se cierra el espacio de terrazgo, una zona de expansión tardía y con núcleos más pequeños. Algunos núcleos que aparecen en el XII en la zona occidental tienen un origen diferente: un punto importante en la red de comunicaciones

35 El caso más destacable es Condado, localidad que dona Fernando I a San Salvador de Oña: «sicut incipit de Vall de Ritero arriba et vadit al valleijo del Vedul et deinde a penna agudiella de Escachos. Et quomodo vadit val de possila arriba et viam de Faç Luengo arriba, et vadit directe per semitarn que vadit de Poblacion a Burgos. Et deinde a la penna de Refaedo et a portiel de Lobo et a Oter de Havi, et a la hayuela de sobre Huespeda. Et quomodo vadit la sierra adelant sicut usque dependant ex una et ex alia parte. Et sicut vadit la sierra usque ad Sanctum Quiricum, et de Sancto Quirico descendit inferius usque al mogion, quod est inter Çeressetam et villam Condado, et exiit in directum a Refoyo et intrat por el valleiio de las carcavas inferius ad ripam fluminis do esta el mogion). ÁLAMO, vol. l, doc. 42 (1057-VI-1).

${ }_{36}$ ALAMO, I, doc. 8 (1011-11-12). La referencia a la «cella» de San Andrés del 967 no es indjcativa de la existencia de Población. Por otro lado, Valdeviffa es para algunos autores un topónimo que esconde a El Almiffé, aunque esta identificación no es muy clara. Vid. Hujoogro Serna, Luciano y GARCí Y SẢNZ DE BARANDA, Julián, Apuntes descriptivos, históricos y arqueológicos..., pág. 74. En cambio, es citado en el diccionario de Pascual Madoz como uno de los dos barrios antiguos de Valdenoceda; vid. MADOz, Pascual, Diccionario geográfico, estadístico e histórico de España y de sus provincias de Ultramar. Provincia de Burgos, Burgos, 1984 (ed. facsimil), pág. 475.

${ }^{37}$ AHN, Clero, San Pedro de Tejada, carp. 377, 3(b) (1044-I-1).

38 ÁLAMO, vol. I, doc. 115 (1102).

39 OCEJA, vol. 1, doc. 65 (C. 1180$)$.

40 ÁLAMO, vol. I, doc. 302 (1193-Vl-26). Se trata del asentamiento surgido en torno al monasterio de San Pedro de Tejada

41 ÁLAMO, vol. I, doc. $320(1199)$

42 OCEJA, vol. I, doc. 90 (1200).

43 lbid., vol. I, doc. 96 (1202-XII-21).

44 lbid., vol. I, doc. 97 (1203).

45 lbid, vol. I, doc. 149 (1248)

Hispania, LVI/2, núm. 196 (1997) 679-707 
(Puente), el desarrollo de una aldea en torno a un priorato en auge (Tejada) y un posible asentamiento intercalar, como parece deducirse del topónimo (Quintana). En cualquier caso, todo indica una colonización culminada en sus aspectos más generales en la primera mitad del xI, a la que sucede un desarrollo basado en la dinámica del sistema feudal. Estos datos, aun siendo elocuentes, no deben tomarse de forma categórica, puesto que la fecha de primera aparición de un topónimo no significa la creación de dicho asentamiento, si bien ofrece una serie de datos indirectos de enorme interés.

La red resultante presenta unas características peculiares. La máxima distancia entre núcleos se sitúa en los 2 kilómetros, con 16 entidades de población en $150 \mathrm{Kms}^{2}$., lo que implica un hábitat con núcleos muy cercanos, con una morfología laxa, extendida, y de escaso volumen demográfico, dentro de un patrón en el que no existen núcleos jerarquizadores ${ }^{46}$. Esta abundancia de pequeñas entidades de tipo aldeano sin vestigios de lugares centrales se asemeja en buena medida a la típica de los "valles" gentilicios estudiados en el norte de la vertiente cantábrica. Además, la presencia de los núcleos religiosos como parte integrante y muy importante del hábitat recuerda algún caso concreto presentado como paradigmático de la constitución de una "comunidad de vallen en esta época ${ }^{47}$.

Las localidades se emplazan mayoritariamente a media ladera, no al borde del Ebro, excepción hecha de Puente de Valdivielso, que debe su creación al paso del río, Población, que también se encuentra en la ribera del Ebro, Panizares y Tartalés de los Montes. Lo normal es que la aldea se encuentre a unos 500-1.000 metros de distancia del cauce, a fin de evitar riesgos de inundaciones y aprovechar al máximo las tierras de la llanura aluvial ${ }^{48}$. Resulta evidente que el proceso de colonización agrícola - preponderantemente agrícola - que se desarrolla durante los siglos anteriores al XI, determina el emplazamiento y la creación misma de los núcleos de población.

La toponimia refuerza esa visión, ya que predomina un tipo de nombres que podríamos calificar de colonización. Así, nos encontramos con abundantes referencias a la geografía, que se pueden interpretar como testimonio de ese proceso colonizador: Arroyo, Arenas, Hoz, Panizares, Quecedo, Toba, Valdenoceda, Valdeviña, Valhermosa ${ }^{49}$. Hay otros topónimos típicamente latino-

46 Vid. MANERo, Fernando, op. cit., págs. 292-293. Este autor analiza los planos de los diferentes pueblos y señala que son núcleos sin evolucionar, en los que la casa precede al pueblo, excepto en Arroyo.

47 Me refiero al valle de Buelna, cuyo análisis sirve a DiEZ HERRERA para analizar la adscripción de un valle a una institución feudal como Covarrubias; op. cit., págs. 31 y ss.

${ }^{48}$ Este tipo de emplazamientos ya fue observado por MARTiNEZ OCHOA, Rosa M. ${ }^{\mathbf{2}}$, «La ordenación del tertitorio en la más vieja Castilla en los siglos $\mathrm{IX}$ a X]»: Boletín de la Institución Fernán González 189 (1977), pág. 284. Vid. MaNERo, Femando, op. cit., pág. 292.

49 OCEJA, vol. I, doc. 90 (1200): «Arroyo»; AHN, Clero, San Pedro de Tejada, Carp. 377, 3 (b) (1044-I-1): «Arenas»; ÁLAMO, vol. I, doc. 320 (1199): «Foz»; OCEJA, vol. I, doc. 147 (1248): «Panizares»; ibid, vol. l, doc. 97 (1203): “Toba»; ALAMO, vol. I, doc. 8 (1011-II-I2): «Keçedo», «Valle de Noçeda» y «Valle de Vinean; ibid, vol. I, doc. 115 (1102): «Vallefermoso». La correspondencia 
romances que se pueden identificar con dicha expansión agraria: Condado, Población (que hace referencia a la creación de un asentamiento), Puente, Quintana y Santa Olalla ${ }^{50}$. Sólo la localidad de Tartalés, que posee un topónimo de probable origen prerromano ${ }^{51}$, se escapa de la regla. En consecuencia, la toponimia es coherente con la hipótesis de una colonización agraria; esto no significa necesariamente que los asentamientos surjan "ex novo", sino que adquieren rango de aldea y, por consiguiente, obtienen un nombre identificativo durante el periodo de colonización. La excepción es Tartalés de los Montes, aldea situada en una zona marginal, un vallejo dentro de la sierra de la Tesla, con una función ganadera; el mantenimiento de un nombre de posible raiz prerromana es posiblemente consecuencia de una importancia previa a la colonización agraria, de su aislamiento frente al desarrollo del resto del valle y de la relación con la cercana zona de la Horadada, donde se encuentra Tartalés de Cilla.

Ante estos datos, debemos preguntarnos sobre la operatividad de la hipótesis de la "comunidad de valle" y su viabilidad en el caso de Valdivielso. Existen aspectos que parecen ir en la dirección de asimilar el valle de Valdivielso con la propuesta de las "comunidades de valle». Se constata una clara identificación del espacio geográfico desde la Alta Edad Media hasta la actualidad. En cuanto a la macrotoponimia, el sufijo "de Bielso" o "de Vielso" parece proceder de un pasado anterior a la época romana, un rasgo que, por otro lado, comparte con otras comarcas no muy lejanas (Lora, Bureba, Caderechas...). Hay que tener en cuenta además que el aprovechamiento agrícola dominante en la actualidad tiene su origen en los siglos centrales del medioevo, pero, con anterioridad, aquí, como en otras zonas cerealeras de alrededor (Losa, Tobalina o la Cuenca de Miranda), el paisaje original era decididamente ganadero y el pasto y el bosque eran los elementos fundamentales dentro de la economía de los "valles" ${ }^{2}$. A todo ello, se añade que las estructuras sociales gentilicias están presentes en el pacto fundacional de San Pedro de Tejada ${ }^{53}$, aunque no es posible afirmar si se trata de la repetición de una tradición monástica o, por el contrario, corresponde al desarrollo particular del valle de Valdivielso.

de este tipo de topónimos con una colonización agraria ha sido defendida recientemente por GARCía DE CORTÁZAR, José Ángel, «Las formas de organización social del espacio del valle del Duero en la Alta Edad Media: de la espontaneidad al control feudal»; Despoblación y colonización del valle del Duero. Siglos vill-Xx. IV Congreso de Estudios Medievales, León, 1995, pág. 18.

50 ÁLAMO, vol. I, doc. 8 (10]1-1\}-12): «Villa Cometato», «Populatione» y «Sancta Eulalie»; OCEJA, vol. I, doc. 65 (C. 1 180): «Quintana»; ibid., vol. I, doc. 96 (1202-XII-2]): «Ponte».

51 OCEJA, vol. l, doc. 97 (1203): «Tartales».

52 MARTínez OCHOA, Rosa M.3., op. cit., págs. 291-292. La dedicación posterior a la agricultura motivó que se produjeran fenómenos de trashumancia hacia otras áreas cercanas, como Butrón, cuyo territorio formó parte de la Merindad de Valdivielso hasta 1903.

53 PEREZ DE URBeL, Justo, op. cit., vol. III, doc. 26 ( $(850-866$ ?): «quod valde execratur regula vel omnes scripturam, aut aliquis oculte consilium cum parentibus, germaniis, filiis, cognatis vel propinquis adprehenderit, sine consilio abbatis vel sancta communis regula».

Hixpania, LVII/2, núm. 196 (1997) 679-707 
Lo cierto es que la morfología del valle lo dota de unidad; el paisaje de la depresión se complementa con las altas cumbres de la Tesla y de los altos de Dobro, que conducen a parajes de aprovechamiento ganadero estival de gran interés. De todo ello se deduce una cierta unidad basada en la orografía y la utilización ganadera. Quizás esa unidad geográfica (percibida incluso en los falsos "Votos de San Millán") remita también a una unidad social que se articularía en torno a una «comunidad de valle».

No obstante, existen claros problemas para aceptar esa identificación. En primer lugar, a pesar de su aparición en los ya referidos "Votos de San Millán", no hay indicios directos de ningún tipo de organización administrativa vinculada con el aparato político castellano. Esta carencia sólo se solventa a finales del xv; no parece muy lógico que un territorio relativamente amplio y bien definido, el cual se supone que conformaba una unidad espacial y social, no tenga una personalidad político-jurisdiccional hasta mucho tiempo después ${ }^{54}$. En ese mismo sentido, no se puede hablar de la presencia de ningún macroconcejo que agrupe a las poblaciones del valle, por lo menos hasta la creación de la Merindad de Valdivielso, institución que nada tiene que ver con la pervivencia de estructuras gentilicias. Respecto a los bienes comunales, cuya excepcional abundancia representa un rasgo definidor de la pervivencia de las "comunidades de valle», aunque en 1972 el $50 \%$ de la superficie de la merindad estaba ocupada por la propiedad colectiva, aquélla que puede identificarse como pervivencia del pasado (eriales para el ganado, zonas cerealeras en las parameras en régimen de arrendamiento) supone en casi todos los casos menos del $2,5 \%$ de la superficie de las distintas aldeas 55 , si bien estos datos plantean problemas, ya que se refieren a nuestro siglo. En todo caso, la propiedad comunal no ha pervivido como en otras zonas no muy lejanas, tales como Valdelómar en Cantabria ${ }^{56}$ o el valle de Tobalina ${ }^{57}$.

Se hace preciso realizar una propuesta de análisis particularizado que se base en el desarrollo histórico de la comarca para interpretar adecuadamente estas circunstancias contradictorias. Parto de la consideración de que Valdivielso fue un espacio dedicado a la ganadería, tal y como ya señalaba unas líneas más atrás. Era una zona de aprovechamiento pecuario en correspondencia con un patrón económico que privilegiaba esta actividad, sin desechar una agricultura rudimentaria y el disfrute del bosque. Durante la época cán-

54 Por indicar un caso que he estudiado, Puebla de Sanabria y su organización como concejo es un ejemplo de una posible identificación entre espacio y unidad político-jurisdiccional; pero, el fuero de Sanabria es de 1220, en plena Edad Media. Vid. Martín VISO, Iñaki, «La feudalización del valle de Sanabria», págs. 53-55.

${ }^{55}$ La excepción es El Almiñé, núcleo en el que este tipo de propiedad comunal suponia el 90,8 $\%$. Frente a ese tipo de propiedad colectiva, se constatan otras formas como los bienes de propios, las juntas vecinales y las comunidades entre distintos pueblos, que, como mucho, se retrotraen al siglo XV1!1. Vid. MANERo, Fernando, op. cit., págs. 119-125.

56 Vid. OrTega ValCÁrCel, Josè, La Cantabria rural..., págs. 15-16.

57 Mapa Topogáfico Nacional, 1: 50.000, hoja 136, donde aparece el espacio ocupado por la mancomunidad de las nueve villas de Sopellano. 
tabra y hasta alrededor de los siglos vI-vII, esta dedicación perduró y se convirtió en un factor determinante en la evolución del territorio. El hábitat era muy inestable, debido al desarrollo de prácticas trashumantes que implicaban, como mínimo, un poblamiento seminómada; esta característica es común a toda la región, aunque aquí se pudo dar una situación más radical. De todas formas, es muy probable que existieran puntos de ocupación humana estacional, algunos de los cuales pudieron tener incluso una mayor continuidad; ejercieron el papel de focos de habitabilidad del valle. No se debe desdeñar la hipótesis, muy factible, de que esos puntos fueran el origen de las aldeas medievales. No se han descubierto todavía vestigios de ocupación de cuevas para la época medieval, por lo que parece desecharse el desarrollo de un hábitat rupestre, que ha dejado abundantes huellas en otras comarcas vecinas ${ }^{58}$.

El hecho de que no se puedan documentar con total seguridad la presencia de castros, que constituían la forma de organización espacial típica del pueblo cántabro, no puede dejarse de lado. Frente a la abundancia de castros en el valle de Manzanedo o en la Lora, sólo se conocen restos de escasa entidad; se puede deducir que el valle de Valdivielso fue un área de interés secundario durante la larga época de perduración de las estructuras gentilicias. No hay núcleos jerarquizadores de ningún tipo. El castro suponía la organización del territorio circundante, con el que mantenía determinados vínculos basados en la explotación económica; interpreto su inexistencia como un indicio de que Valdivielso, como valle, era una zona subsidiaria utilizada para el aprovechamiento ganadero, un área a la que acudían las «gentes» con sus ganados procedentes de los núcleos de asentamiento más fijos, los castros de otras comarcas. El aislamiento geográfico favorecía que actuara como un territorio de reserva dentro del sistema económico cántabro, una zona de uso pecuario, un inmenso pastizal en el que no existían más que pequeños puntos donde se asentaban temporalmente estos ganaderos trashumantes. Se puede hablar de un auténtico "hinterland" ganadero en una zona de frontera con los autrigones, primero, y con la zona más romanizada, después, el cual, gracias a su inaccesibilidad, se hallaba sólidamente controlado por los cántabros.

Esta hipótesis explicaría buena parte de los datos que he ofrecido con anterioridad. No existirían restos arqueológicos de importancia, ante la falta de asentamientos continuados; la toponimia prerromana, que sólo aparece en el macrotopónimo, es coherente con la comprensión del valle como un todo, mientras no se documenta ese tipo de nombres en las aldeas -salvo Tartalés

58 Este hábitat rupestre ha sido estudiado desde la perspectiva de los eremitorios. Pero, como comenta Castellanos, Santiago, «Aproximación a la historia política del Alto Valle del Ebro durante los siglos v-vı d.C.»: Brocar 18 (1994), pág. 124, la profusión de cuevas no se puede explicar únicamente desde la perspectiva del eremitismo, sino que esa abundancia, documentada en toda la región del Alto Ebro, parece indicar que una parte considerable de la población vivía en cuevas. Un planteamiento centrado en este tipo de hábitat en La Rioja es el de RJaÑo, Eugenio, «Eremitorios rupestres y colonización altomedieval»: Studia Historica. Historia Medieval 13 (1995), pags. $47-58$.

Hispania, LVIL2, תúm. 196 (1997) 679-707 
de los Montes- ya que sólo eran puntos de asentamiento inestable. Por supuesto, todo ello es coherente con el desconocimiento de cualquier tipo de organización autóctona.

Desde el siglo vi se advierte un proceso de agrarización o colonización agraria en toda la región, que se aceleró considerablemente en las dos centurias siguientes en todo el norte peninsular. Desde los estudios de A. Barbero y M. Vigil, casi todos los autores aceptan la tesis de que tras una primitiva fase de recogida de alimentos y prácticas predominantemente ganaderas, las sociedades gentilicias acceden paulatinamente a una fase superior que supone la práctica sistemática de la agricultura ${ }^{59}$. Esta evolución trajo de manera inevitable cambios en la sociedad gentilicia, ya que la evolución en favor de la agricultura representaba un abandono de las prácticas ganaderas extensivas, un elemento clave en la articulación social, y una apuesta decidida por la sedentarización definitiva. Fueron las contradicciones internas las que produjeron esta desvertebración, al ser imposible el mantenimiento del patrón económico previo. Teniendo en cuenta en todo momento los diferentes ritmos que dicha desvertebración tuvo según áreas geográficas, la secuencia de las transformaciones se articularían en torno a cuatro grandes cambios: la lenta transición del matriarcado al patriarcado, la ruptura paulatina de los vínculos de parentesco como aglutinantes sociales en beneficio de unidades familiares más restringidas, la intensificación de la producción agraria, que supone sedentarización y propiedad privada, y la jerarquización social como consecuencia de la apropiación privada y de la transformación de las viejas jefaturas militares en jefaturas vitalicias de tipo político-militar ${ }^{60}$. No es mi intención aquí profundizar sobre este apartado, que bien merecería toda una monografía, sino simplemente referirme a este proceso. El resultado será un deterioro de la situación anterior que favorecerá el paso hacia un sistema feudal, gracias a las carencias de las comunidades de aldea y al desarrollo de una clase aristocrática, cuyo origen se remonta a este periodo ${ }^{61}$.

La zona septentrional de la actual provincia de Burgos, es decir, la primitiva Castilla, fue una región en la que la persistencia de los esquemas gentilicios tuvo una especial duración, hasta el punto de que todavía en el siglo $\mathrm{x}$ se podían observar determinados rasgos como la propiedad comunitaria, las relaciones de parentesco amplio o el sistema de adopción, que se remontan al pasado ancestral ${ }^{62}$. Durante los siglos VIr al $\mathrm{IX}$, se produce un despegue muy dinámico en esta zona, resultado de la aplicación del modelo de pequeña pro-

59 Barbero, Abilio y Vıgil, Marcelo, Sobre los orígenes..., Barcelona, 1974, págs. 55 y ss., y La formación del feudalismo en la Península lbérica, Barcelona, 1978, págs. 365 y ss.

${ }_{60}$ Mínguez, José M. ${ }^{2}$, «Antecedentes y primeras manifestaciones del feudalismo astur-leonés»: En torno al feudalismo hispánico. I Congreso de Estudios Medievales, Ávila, 1989, págs. 97-107.

6I Sobre el proceso de feudalización en Castilla, es de especial interés el artículo de Álvarez BORGE, Ignacio, «El proceso de transformación de las comunidades de aldea: una aproximación al estudio de la formación del feudalismo en Castilla (siglos x y xI)»: Studia Historica. Historia Medieval V (1987), págs. 145-159.

62 Martinez Garcla, Luis, «La sociedad burgalesa en la Alta Edad Media»: BAEM, pág. 365. 
ducción familiar, en torno a las comunidades de aldea ${ }^{63}$. Para J. J. García González, el punto de arranque se encontraría en el influjo visigodo que actuó como precipitante a través de la conquista del territorio a fines del siglo vi ${ }^{64}$; sin embargo, ya he manifestado en otro lugar mi disconformidad con esa posición, por cuanto disminuye el papel de las contradicciones internas de la propia sociedad indígena y además no se puede probar con los datos que poseemos ${ }^{65}$.

La desaparición del reino visigodo marcó de forma decisiva la evolución posterior del área y conllevó un desarrollo de la agrarización. El espacio situado al sur deja de ser un lugar de posible rapiña, por lo que se profundiza en la colonización agraria ya comenzada con anterioridad. No obstante, el peso de las prácticas comunales, vestigios del pasado gentilicio, formarán una parte consustancial de la colonización, por lo menos en esta fase inicial que podemos fechar hasta finales del siglo Ix. La instauración de la pequeña propiedad individual en el marco de las comunidades de aldea, creadas como nuevos modelos de organización en esta época, implicó la generalización de unas diferencias internas, dentro de la comunidad, que anuncian la sociedad feudal. Esa pequeña propiedad individual es la fórmula mediante la cual los diferentes miembros de una comunidad acceden al disfrute de las tierras en cultivo, si bien es cierto que paralelamente se mantiene una propiedad comunal. La consecuencia de todos estos procesos en el poblamiento es la génesis de la aldea como forma de hábitat predominante, en consonancia con la apuesta por la sedentarización que lleva ímplicita la colonización agraria. $\mathrm{Si}$ los asentamientos del periodo final del modelo gentilicio eran ya semi-nómadas e incluso sedentarios, ahora el patrón tiene su base únicamente en la sedentarización. La política de creación de un paisaje agrario, que nace de las propias carencias de la ganaderia extensiva, trajo consigo este modelo de poblamiento.

En Valdivielso, se puede también documentar este proceso. Los documentos procedentes del monasterio de Santa Eulalia de Valdivielso del siglo XI nos permiten observar los progresos de esa colonización agraria ${ }^{66}$. Así, se donan "rationes" "cum suas terras, vineas, pumares, ortares..." ${ }^{67}$, y el monasterio aparece "cum suas ereditates, terras, vineas, pumares, ortales, molinos, lecto

63 García GoNZÁlez, Juan José, «Del castro al castillo. El cerro de Burgos de la Antigüedad a la Edad Medjay: Cuadernos Burgaleses de Historia Medieval 2 (1995), págs. 136-142.

64 Vid. «lglesia y rejigiosidad en Burgos en la Alta Edad Median: BAEM, págs. 362 y ss.; «Iglesia y religiosidad en Burgos en la Plena Edad Media», págs. 309-310 y «Fronteras y fortificaciones...», págs. 19 y 48.

65 Vid. «Poblamiento y sociedad en la transición al feudalismo en Castilla; castros y aldeas en la Lora burgalesay: Studia Historica. Historia Medieval 13 (1995), pp. 3-45.

${ }_{66}$ Estos documentos deben ser leídos con precaución, ya que LóPEz MATA, Teófilo, Geografía del Condado de Castilla a la muerte de Fermán González, Burgos, 1957, pág. 91, observó cómo la data (1042-1044) no correspondía con el reinado de Fernando I, por lo que serian posteriores a 1054. De todas formas, creo que se pueden fechar en el siglo xI.

67 AHN, Clero, San Pedro de Tejada, carp. 377, 3(c) (¿1042-1044?).

Hispania, LVII/2, núm. 196 (1997) 679-707 
de piskare in flumen Ebro» ${ }^{68}$. También poseemos información procedente de los fondos del monasterio de Oña, donde se encuentra un traslado de 1598 de un diploma del año 1032 - por lo que se pueden mantener ciertas reticencias acerca de su veracidad- en el que se dan al cenobio diversos bienes, entre ellos: "en Valdibielso, las viñas que fueron de Fernant Gonzálvez, el alavés" 69. La ausencia de datos para los siglos anteriores obliga a utilizar estos testimonios del siglo XI como referentes, puntos de llegada de esa colonización. Quizás de la presencia de sernas, de las que hay una noticia en el siglo XII ${ }^{70}$, pueda deducirse una colonización agraria fuertemente influida por las tradiciones comunales, aunque existen otras posibilidades ${ }^{71}$.

Durante este proceso de colonización, se puede datar la creación de las aldeas de Valdivielso como tales; el documento fundacional de San Salvador de Oña no es más que la formalización escrita de unas entidades que se puede sospechar que ya existían tiempo atrás como aldeas. El creciente papel de las actividades agrícolas precisaba, como ya se ha dicho, una mayor fijación del hábitat, estructurado en torno a los terrazgos, pero de forma laxa, de acuerdo con una agricultura que se basaba en la actuación de pequeñas comunidades e incluso familias nucleares. La ganadería de tipo extensivo, que se irá convirtiendo en un monopolio de los grandes señores feudales, se desplazará geográficamente hacia las zonas más altas, hacia Butrón, o lo que es igual, el Partido de los Altos, una porción de la Lora que tuvo una estrecha relación con Valdivielso hasta 1903. Esto explica el interés de San Salvador de Oña por hacerse con dominios en diversos lugares de los Altos: Dobro, Escóbados, Pesadas de Burgos, Villalta, etcétera. No obstante, el papel de la ganadería siguió pesando en Valdivielso hasta el siglo XVII, cuando hay testimonios de los intentos por mantener intangibles las zonas pastizables ${ }^{72}$. Sea como fuere, ese desplazamiento de las actividades ganaderas hacia la región de los Altos, supuso, por una parte, la subordinación del área a Valdivielso durante toda la Edad Media y hasta 1903; por otra parte, la necesidad de una trashumancia de corto recorrido imposibilitó que los campesinos de Valdivielso se pudieran dedicar a esa actividad, que sólo un gran señor, como los monjes de Oña, a través de su priorato de San Pedro de Tejada, podía llevar a cabo.

68 Ibid., 3(a) (i1042-1044?).

69 OCEJA, vol. I, doc. 1 (1032-XI-18).

70 El prior de San Pedro de Tejada recupera «illam sernam que est a la presa de Sancta Eulalia et aliam (...) est in loco que vocatur Oteruelos»; ibid., vol. I, doc. 66 (c. 1180).

7 Sobre esa posibilidad, vid. Botel LA POMBO, Esperanza, La serna: ocupación y explotación del espacio en la Edad Media (800-1250), Santander, 1988, págs. 24-33 y «Las sernas-prestación en el espacio burgalés en la Edad Media: manifestación de la superposición señorial»: $B P E M$, págs. $677-697$.

72 Vid. MANERo, Fernando, op. cil., pág. 65. De todas formas, también en los documentos de Santa Eulalia puede todavia verse esa importancia en la fórmula general de pertenencia: «et portione in montes et in fontes, in pratis, pascuis, in aquis aquarum et usque ad petru et divisa in totas villas de Bielso ad suso»; AHN, Clero, San Pedro de Tejada, carp. 377, 3 (a) (i1042-1044?). 
No sólo se constata la influencia "a posteriori» de las instituciones monásticas, sino que parece muy claro que el impulso "monástico" se sitúa en las raíces del mismo proceso de colonización agraria. La práctica totalidad de los estudios actuales sobre la Alta Edad Media ibérica se preocupan por el papel de la cristianización y de los centros monásticos y su relación con la colonización. Es evidente que el proceso cristianizador de estas regiones favoreció los cambios dentro de la sociedad gentilicia. Pero, la expansión del aparato político visigodo no representó la instauración sistemática de una organización eclesiástica con base episcopal, sino que fueron los ermitaños y otras formas marginales dentro del cristianismo oficial quienes se encargaron de esa labor cristianizadora; se promocionaron además formas particulares, como el pactualismo o el monacato dúplice, que eran una síntesis de elementos cristianos con algunos rasgos típicos de la organización gentilicia. No obstante, la actividad evangelizadora de los ermitaños no cristalizó hasta que la agricultura se convirtió en la principal actividad economica ${ }^{73}$; es decir, estos ermitaños coadyuvaron, mediante su labor misional, en el proceso de colonización, pero éste es anterior y, en cierta medida, autónomo. En todo caso, el progreso de la agricultura y la ruptura de las agrupaciones gentilicias motivo que se generaran una serie de comunidades alejadas de los cánones eclesiásticos y que se enmarcan en las nuevas formas de organización social ${ }^{74}$. La región de la primitiva Castilla presenta abundantes ejemplos de estos peculiares cenobios y sus realizaciones en estos siglos. No parece que Valdivielso haya estado alejada de este modelo; por el contrario, el impulso monásticoeclesial es un factor clave en la colonización.

Determinados lugares del valle tienen un origen monacal. El caso más evidente es Santa Olalla de Valdivielso, cuyo topónimo es recuerdo del monasterio o iglesia - las diferencias en esta época son imposibles de dilucidar- de Santa Eulalia, que existe, al menos, desde el siglo XI, cuando es donada a Oña ${ }^{75}$. Los diplomas que poseemos sobre esta institución, a los que ya he hecho referencia, hablan de "quintas" y «portiones", por lo que parece que este monasterio poseía una historia anterior. A pesar de que se genero posteriormente un núcleo de población autónomo, aún en el siglo XIII había un "monasterio de Santa Olalia» ${ }^{76}$. Otro lugar en el que probablemente la instalación de un monasterio fue un momento decisivo en su consolidación como aldea fue Población de Valdivielso. La «cella» que aparece en una información dudosa del siglo x se ha identificado con San Andrés de Población; en la donación fundacional de Oña se cita a San Andrés de Población, sin incluir una identificación como «ecclesia», mientras Población como tal, sin el apelativo de San Andrés, surge por primera vez en 1057, de forma indirecta, y directa-

73 García Gonzalez, Juan José, «lglesia y religiosidad en la Plena Edad Media», pág. 301.

74 Minguez, José M. ${ }^{a}$, «Ruptura social e implantación del feudalismo en el Noroeste peninsular (siglos vitl-X)»: Studia Historica. Historia Medieval III (1985), págs, 17 y ss.

75 ÁLAMO, vol. I, doc. 8 (101 1-II-12): «Ecclesia Sancte Eulabie cum integritate».

$76 \mathrm{lbid}$., vol. II, doc. 684 (1279-V-2 I): «la nuestra tierra que es en Tova, que pertenesçia al nuestro monasterio de Santa Olaliass.

Hispania, LVII/2, núm. 196 (1997) 679-707 
mente en $1199^{77}$. En el siglo XIII, se data todavía un monasterio de San Andrés de Población que arrienda San Salvador de Oña a un tal Martín Juan ${ }^{78}$.

Pero los datos más interesantes se encuentran en la fundación de San Salvador de Oña. En esta donación, a la que me he referido numerosas veces, presenta tres localidades con su iglesia (Condado, Quecedo y Valdeviña) y seis iglesias: San Andrés de Población, San Pedro de Tejada y Santa Eulalia y otras tres no identificadas. Únicamente Valdenoceda aparece sin ningún tipo de entidad religiosa. Esta información subraya el impulso monástico-eclesial. Pero $i$ a qué es debido que juege este papel?

J. J. García González, en algunos de sus trabajos, considera que el monacato prebenedictino es un vestigio del "comunitarismo" y ofrece un carácter retardatario ${ }^{79}$. Por tanto, su valoración es bastante negativa, al definir a este monacato como un epígono de la sociedad gentilicia con ciertos elementos novedosos procedentes de la colonización, aunque incapaz de asumir plenamente la nueva situación, donde la "pequeña propiedad" es el eje social de todo el proceso. Mi opinión es que fue un movimiento capaz de realizar una síntesis entre los vestigios comunitarios y la agrarización, haciendo posible así la colonización de numerosas áreas de Castilla; no fue una solución marginal, sino adecuada a la situación existente ${ }^{80}$, cuyo éxito fue evidente hasta la implantación del feudalismo.

Valdivielso era una zona de asentamiento inestable, un espacio subordinado. La agrarización se tuvo que realizar desde comunidades que organizaron el territorio, rompiendo la dependencia de zonas castrales, externas al valle; las creencias representaban un aspecto básico entre los miembros de estas comunidades cara a cimentar su articulación social. Los ermitaños existentes debieron tener contactos con estas comunidades y fueron copartícipes en la creación de asentamientos. Influidos por las tradiciones comunales previas, estos ermitaños crearon y desarrollaron un tipo de comunidades monásticas de carácter laxo, en las que también intervienen laicos, que se convirtieron en los auténticos elementos organizadores de la colonización en Valdivielso; fueron así los puntos de referencia de los nuevos núcleos, que no necesariamente se crearon "ex novo". Los habitantes utilizan el mecanismo de estos «monasteria» o «ecclesia» para dotar de personalidad a las posteriores aldeas. Existen abundantes ejemplos en el resto del territorio castellano. El proceso pudo ser el siguiente: desde los puntos de uso ganadero, se establece el nuevo hábitat, que los utiliza como articuladores de la colonización; para organizar

$77 \mathrm{lbid}$, vol. I, doc. 42 (1057-Vl-1): «et vadit directe per semitam que vadit de Poblacion a Burgos...», y doc. 320 (1199); «unum linar in Poblacion».

78 Ibid., vol. II, doc. 446 (1228-1II-21): «illud nostrum monasterium Sancti Andree de Poblaçion».

79 Para este historiador, era una vía muerta que sirvió preferentemente para reciclar como agricultores a pastores ancestrales descolocados y como productores comunitarios a rústicos y ermitanos desesperanzados en su soledad de agricultores privados. Vid. «Iglesia y religiosidad en Burgos en la Plena Edad Mediay, pág. 319.

80 Vid. MinGUEZ, José M.", «Ruptura social...», págs. 21-22.

Hispania, LVIL/2, núm. 196 (1997) 679-707 
los asentamientos, las comunidades usan el expediente de los "monasteria", con influjos de los ermitaños, a fin de conferir a los mismos unos lazos comunales, más allá del parentesco; de idéntica manera, se edifica y consolida un lugar en el que se pueden centralizar determinadas actividades que afectan a todos los miembros ${ }^{81}$. Esta situación de base explicaría la vitalidad de los núcleos religiosos en Valdivielso en la Alta Edad Media. Por otro lado, la actividad eclesial propugnaba una territorialización del valle en favor de unas aldeas con límites bien precisos. ¿Se rompra entonces la unidad del valle? Más bien se ocupaba de forma colonizadora un «hinterland" que había perdido su interés tras la quiebra del sistema económico preponderantemente ganadero. ¿Hubo, por tanto, aculturación? En todo caso, sólo en parte, ya que la cristianización supuso un claro proceso aculturizador, pero los núcleos monásticos nacen de una sociedad en desvertebración y son más bien manifestaciones de ésta y no de una organización eclesiástica que se impondrá en los siglos XI y XII, con la expansión de San Salvador de Oña.

No fue la única forma de creación de aldeas. Otras como Arroyo, Hoz, Panizares, Puente-Arenas, Quintana o Toba quizás no respondan a ese modelo. Pudieron ser comunidades que no necesitaron de ese expediente para su articulación; pero, curiosamente, su datación es posterior, es decir, que representan la cristalización de una segunda oleada colonizadora, inserta más plenamente en la dinámica del sistema feudal. De cualquier forma, el impulso monástico es muy significativo.

Ese impulso inicial condujo al desarrollo de las propias comunidades, en las que las iglesias mantuvieron una cierta importancia. Se fueron generando unas diferencias internas más nítidas, dando lugar a la creación de una élite local que basaba su poder en una superioridad económica y que controlaba las decisiones de la comunidad ${ }^{32}$. En Valdivielso, tenemos el caso concreto de Salvador González que compra diversas partes del monasterio de Santa Eulalia de Valdivielso a Muño Núñez, Gonzalo Escaréquiz, Moriel Núñez y Obieco Gudestioz ${ }^{83}$; a través de estas compras, Gonzalo Salvadórez consigue el control de Santa Eulalia.

Esta élite iniciará una dinámica de ruptura con los lazos comunales, de acuerdo con sus intereses. De todas formas, no podían romper la tradición

81 Algunas excavaciones han constatado la presencia de silos de almacenamiento situados en el interior de centros de culto del periodo altomedieval; vid. REYES TélLEz, Fernando y MENÉNDEZ ROBLES, M. ${ }^{2}$ Luisa, «Excavaciones en la ermita de San Nicolás. La Sequera de Haza (Burgos)»: Noticiartio Arqueológico Hispánico 26 (1985), págs. 171 y ss.

${ }_{82}$ Esta creciente diferenciación interna, que no es más que una profundización bajo nuevas bases de las diferencias iniciales dentro de la comunidad, ya fue postulada por PAstor, Reyna, «Sobre la articulación de las formaciones económico-sociales: comunidades de aldea y señoríos en el norte de la Peninsula Ibérica (siglos X-X1II)»: Estructuras feudales y feudalismo en el mundo mediterráneo (siglos X-XII), Barcelona, 1984, págs. 99-101; ÁLVAREZ BORGE, Ignacio, «El proceso de transformación de las comunidades de aldea...», págs. 147 y ss. es un estudio empírico de esa diferenciación interna.

${ }^{33}$ AHN, Clero, San Pedro de Tejada, carp. 377, 3 (¿1042-1044?).

Hispania, LVIJ/2, nu่m. 196 (1997) 679.707 
comunal y resistir a los grandes propietarios que iban consolidando sus posiciones, en este caso, San Salvador de Oña. Por esa razón, se utilizó la behetría como la forma mediante la cual se implanta una efectiva dependencia feudal, sin perder por ello la personalidad comunal de los núcleos. Todo parece indicar que la behetría fue el expediente más utilizado para articular las aldeas dentro del sistema feudal durante los siglos XI y XII ${ }^{84}$. Cuando se redacta el «Becerro de las Behetrías», en 1352, Valdivielso, que pertenece a la Merindad de Castilla la Vieja, nos ofrece un paisaje repleto de behetrías. Condado, Hoz de Valdivielso, Panizares, Población de Valdivielso, Puente-Arenas, Quecedo, Santa Olalla, Valdenoceda y Valhermosa son behetrías ${ }^{85}$; Celada, Quintana de Valdivielso, Toba y quizás El Almiñé son "yermos" ${ }^{86}$, mientras sólo Arroyo, Tartalés de los Montes y Tejada son solariego el primero y abadengo las otras dos localidades ${ }^{87}$, si bien Condado, Valdenoceda y Santa Olalla presentan una situación mixta de behetría y solariego (como tal o abadengo) ${ }^{88}$. Si dejamos aparte la progresiva pérdida de contenido de la behetría, ya estudiada por otros autores ${ }^{89}$, hay que resaltar que inicialmente esta institución significa la existencia de un grupo de «diviseros» de la localidad, quienes insertan la realidad aldeana en otras que superaban ese marco, como son las instancias feudales superiores, sin que por ello se perdiera la identidad del núcleo. Supone la preexistencia de una élite de carácter local, identificada con los infanzones $\mathrm{u}$ otros tipos de nobleza local ${ }^{90} \mathrm{y}$, por tanto, de una colonización antigua que ha producido una diferenciación interna bastante profunda. Sólo el desarrollo plurisecular de las aldeas da inteligibilidad a la actividad de un grupo intermedio: los «diviseros». La pervivencia, aunque muy alejada de su contenido inicial, ante la masiva presencia de los Manrique como "diviseros" o "señores naturales", de las behetrías en Valdivielso en el XIV indica una peculiar resistencia de esta forma de señorío que se debe relacionar primero con un largo proceso de afirmación de la aldea, pero también con la incapacidad del monasterio de Oña por romper con este modelo. En

$\$ 4$ Vid. Estepa Díz, Carlos, «Estructuras de poder en Castilla (siglos Xil-Xill). El poder señorial en las merindades burgalesas»: BPEM, págs. 257-258.

${ }^{85}$ Becerro de las Behetrías, vol, II, págs. 498, 519-520, 523 y 527-530.

8́ lbid., vol. II, págs. 537-539.

87 lbid., vol. II, págs. $466-467$ y 476.

88 Curiosamente, numerosas localidades de los Altos son también behetrias: Ahedo de Butrón, Porquera de Butrón, Tubilleja, Tudanca, Escóbados de Arriba, Escóbados de Abajo, Huéspeda, Madrid de las Caderechas y Herrera de Valdivielso.

${ }_{89}$ Vid. Clavero, Bartolomé, «Behetría 1255-1365. Crisis de una institución de señorío y de la formación de un derecho regional en Castillan: Anuario de Historia del Derecho Español XLIV (1974), págs. 201-342; ÁLVAREZ BoRGE, Ignacio, «Sobre las relaciones de dependencia en las behetrías castellanas en el siglo xull: hipótesis a partir del caso de Las Quintanilias»: Señorío y Feudalismo en la Península lbérica (siglos XII-XIX), Zaragoza, vol. II], 1993, págs. 225-240; EsTEPA DíEZ, Carlos «Formación y consolidación del feudalismo en Castiłla y León»: En tomo al feudalismo hispánico. I Congreso de Estudios Medievales, Ávila, 1989, págs. 230 y ss.

90 Vid. ESTEPA Diez, Carlos, «Formación y consolidación...", págs. 234 y ss. 
realidad, tal pervivencia debe explicarse en clave de resistencia de vestigios comunales dentro de las comunidades de aldea, gracias a su enorme tradición y persistencia ${ }^{91}$

La behetría supone una manera de incorporarse a los modelos señoriales que, en el caso que nos ocupa, se hizo desde la realidad de unas aldeas afirmadas. La behetría no se identifica con el valle, por lo menos inicialmente, ya que su origen está en cada núcleo. En todo caso, el hecho de que el espacio de Valdivielso sea más o menos homogéneo en cuanto a la presencia de behetrías se debe a la forma en que se realizó la colonización y quizás en una labor homogeneizadora por parte de San Salvador de Oña, como señor feudal,

Otro rasgo identificativo es la inexistencia de un centro territorial que organice administrativamente el espacio, a pesar de algunos testimonios poco clarificadores. Así, el diploma fundacional de Oña señala una "Castella Vetula" en la que no aparecen los núcleos de Valdivielso ${ }^{92}$, si bien parece que se trata de una identificación de dicho término con Tobalina y Cuesta-Urría, es decir, es una metonimia del nombre genérico. De cualquier forma, parece claro que, en el caso de que existiera una entidad definida desde el valle de Valdivielso, ésta pasó en el siglo XI a ser considerada como parte integrante de Castilla Vieja, puesto que no se vuelven a oponer ambos términos, dentro del alfoz de Tedeja ${ }^{93}$. En cualquier caso, no hay ninguna noticia escrita que mencione algún tipo de organización administrativa más allá de la simple mención al valle.

Sin embargo, existen elementos que pueden significar una estructura territorial, aunque no llegue a la denominación de alfoz. Podría deberse a que en el momento de generalización del uso de ese término dicha estructura se encontrara en decadencia. Así, en el propio documento fundacional de San Salvador de Oña, aparece la donación de una "Villa Cometato", que en 1057 es entregada nuevamente por Fernando I ${ }^{94}$. Este curioso topónimo corresponde a una localidad actual: Condado. Pero, debe observarse cómo se refiere a una forma administrativa concreta. No parece demostrable la existencia de un condado de Valdivielso en los oscuros orígenes de Castilla con los datos que poseemos en la actualidad; a pesar de ello, bien pudo tratarse de un punto de referencia del poder condal castellano. Por otro lado, es interesante com-

91 lbid., págs. 252-253. En mi opinión, no se trata de un sef̂orio colectivo que tiene su origen en una nobleza local que posee un poder derivado del control de la comunidad de valle, sino un señorío basado en cada núcleo de población. Valdivielso no se reconoce como una behetría; es un conjunto de behetrías, cada una de ellas autónoma.

${ }_{92}$ Inmediatamente después del listado de bienes en localidades de Valdivielso, se señalan otros «in Castella Vetula»: San Juan de la Hoz en Cillaperlata, Revilla de Tobalina, Cillaperlata, Quintanaseca, Arroyuelo, Villapanillo y Quintanas. ÁLAMO, vol. J, doc. 8 (1011-Jl-12).

93 Ésta es la postura que defiende EsTEPA Diez para quien el caso de Valdivielso sería un ejemplo de la integración de demarcaciones menores en otras mayores; «El alfoz castellano en los siglos IX al XIIm: En la España Medieval. Estudios dedicados al profesor D. Ángel Ferrari Núñez, Madrid, vol. I, 1984, pág. 334.

94 ÁLAMO, vol. I, doc. 42 (1057): «villam quam vocitant Condado».

Hispasia, LVI11/2, núm. 196 (1997) 679-707 
probar la existencia de restos de un torreón llamado "Castillo de Toba", sobre una peña al suroeste de la localidad de igual nombre, a unos cuatro kilometros de Condado ${ }^{95}$. Varios autores lo han situado cronológicamente en los primeros siglos de la Reconquista, con misiones de vigilancia sobre el valle ${ }^{96}$. De todas formas, pudo ser un primitivo sistema de defensa de las poblaciones del valle reutilizado por el poder condal para instaurar su dominio y para manifestarlo. Esta fortificación podría encontrarse en relación con Condado, que formaría el núcleo desde el que se organizaba el poder condal sobre el valle, sin generar una estructura administrativa.

De cualquier manera, la hipótesis es muy difícil de demostrar y sólo indicaría la presencia del poder condal, pero no así la existencia de una estructura territorial consolidada, ya que si hubiera sido así ¿por qué no dejó rastro alguno en toda la Edad Media? Si se acepta la integración en el alfoz de Tedeja -aún cuando la presencia de alfoces no tiene por qué ser monocorde en todo el territorio-, se estaría subrayando el carácter de «hinterland» de Valdivielso, al ser un mero espacio controlado desde otro lugar. Claro que, siguiendo con esta hipótesis, se contempla a Valdivielso desgajado de la zona occidental, anteriormente cántabra, en favor de su zona oriental. En definitiva, la inexistencia de un territorio administrativo propio puede mostrarse como prueba de que Valdivielso no era un espacio autodefinido socio-políticamente.

El poder condal, tal y como aparece en la donación fundacional de Oña, estructura su control sobre Valdivielso en torno a las iglesias ${ }^{97}$. No es nada extraño, puesto que también sucede en otras zonas, pero es significativo de la forma en que se articula el poblamiento del valle. Las entidades religiosas constituyen los ejes que vertebran los asentamientos. En otras comarcas, el alfoz se convierte en el principal protagonista de la organización condal, con una misión administrativa, aunque no es la única ${ }^{98}$. Aquí, en cambio, la dependencia no crea una organización de carácter administrativo, sino que tiene su fundamento en el control de las iglesias. No voy a entrar en el espinoso asunto de si se trata de propiedad dominical o dominio señorial, puesto que lo que interesa resaltar es precisamente la forma peculiar que alcanza el control condal, que no varía en cuanto al contenido de lo que ha señalado Álvarez Borge para otras zonas. De cualquier forma, la donación de Condado por Fernando I al monasterio de Oña muestra una localidad con unos límites bien precisos y con una fuerte articulación interna ${ }^{99}$. Puede servir de muestradel impulso

9s Mapa Topográfico Nacional, 1: 50.000, hoja, 135, 42. 49" $10^{\prime \prime} \mathrm{N}-0.0^{\circ} 07$ ' $10^{\prime \prime} \mathrm{E}$.

$96 V i d$. Miguel OJEDA, Gonzalo, «Torres y castillos burgaleses»: Boletín de la Institución Fernán González 157 (1961), pág. 718; Osaba y Ruiz de Berenchun, Basilio, «Moenia Sacra: poblados, monasterios y castillos desaparecidos en la provincia de Burgos): Boletín de la Institución Fernán González 166 (1966), pág. 59.

97 Vid. Estepa DiEz, Carlos, «Formación y consolidación...», págs. 185-186.

98 Álvarez Borge, Ignacio, Monarquía feudal y organización territorial. Alfoces y merindades en Castilla (siglos X-XIV), Madrid, 1993, págs. 17-54.

99 Vid. nota 32. Estepa Díez considera esta donación como un ejemplo de dominio señorial; "Formación y consolidación...», págs. 203-205. 
"aldeanizador» del poder político, al servirse para crear y consolidar su dominio precisamente en las iglesias, elementos claves en ese proceso.

Ningún análisis de Valdivielso en la Edad Media puede dejar de lado la actuación de San Pedro de Tejada, institución en manos de San Salvador de Oña, de la que fue priorato, cuya función fue la de adscribir el valle a un señorío feudal. A lo largo de los siglos XI, XII y XIII, los documentos escritos informan de la existencia de bienes y rentas del priorato en Arenas, Arroyo, Hoz, Población, Puente, Quecedo, Quintana, Santa Olalla, Tartalés de los Montes, Toba, Valhermosa y Vercedo (paraje cercano a Arenas de Valdivielso, uno de los dos núcleos que forman el avtual Puente-Arenas), así como en Valdivielso de forma genérica ${ }^{100}$. La actividad de este centro generó un núcleo de población aledaño, Tejada, que completa el cuadro del dominio. Pocos lugares quedan en Valdivielso al margen de ese dominio: Condado, Panizares, Valdenoceda y Valhermosa-El Almiñé, aunque de todos ellos únicamente en Panizares desconocemos cualquier tipo de patrimonio de San Salvador de Oña para este periodo.

Gracias a San Pedro de Tejada, el monasterio de Oña organiza el valle como un "hinterland" agrario. Sin embargo, lo realiza a través de las entidades de poblacion, que han adquirido una identidad específica que nada tiene que ver con un genérico apelativo a Valdivielso. Dentro del dominio son una parte efectiva que lo articula, $o$, dicho de otra forma, no se controlan bienes en el valle, sino en las diferentes aldeas que componen dicho valle. Con la actividad del priorato se formalizan las relaciones feudales, pero dentro de un marco de referencia aldeano ${ }^{101}$.

Después de esta exposición, parece evidente que el valle de Valdivielso adquiere sus rasgos como resultado de una colonización agraria basada en la creación de aldeas. No hay indicios suficientes como para probar la pervivencia ni tan siquiera la existencia de un "valle" gentilicio anterior, al menos tal y como se define por la escuela de la "organización social del espacion. La realidad es que son las aldeas los elementos estructuradores del valle, por lo que el supuesto "valle" gentilicio no es operativo; únicamente a través de la actividad de los núcleos aldeanos y a partir de su formación y consolidación, se puede comprender la organización de Valdivielso en época medieval. El desarrollo de la behetría como forma de articulación de cada aldea en el sistema feudal, la escasez manifiesta de zonas de uso comunal y la inexistencia de estructuras políticas de base comarcal que recordaran la unidad socio-política del "valle»,

$100 \quad$ OCEJA, vol. l, docs. 47 (113]), 65 (c. 1180), 66 (c. 1180), 78 (1193-XII-28), 83 (1197), 90 (1200), 93 (1201-XI), 91 (1201), 96 (1202-XII-21), 94 (1202), 97 (1203), 101 (1207), 133 (1241III-27), 135 (1241-[I]-29), 136 (124l-V-2), 137 (1241-VII-3), 229 (1279-V-22), 252 (1284-VIJl-7) y 253 (I284-VII]-7); ibid., vol. II, doc. 383 (1293-[-15); ÁLAMO, vol. II, docs. 446 (1228-III-2]) y $679(1279-1-28)$.

101 Es interesante observar que la jerarquización del espacio que realiza San Pedro de Tejada presenta rasgos de debilidad, al constituirse como un organismo con una fuerte dependencia respecto de una institución exterior al valle. Esta "débil» jerarquización es una caracteristica común a otros «valles», aunque sería necesario definir y clasificarla.

Hispamia, LV!1/2, nủı. 196 (1997) 679-707 
son pruebas que parecen ir en contra de un supuesto "valle». El impulso monástico, reflejo de acciones llevadas a cabo por comunidades de laicos, constituye la epidermis de un proceso largo y complejo de colonización.

Queda claro que no se debe confundir la percepción geográfica con el aprovechamiento económico, ni ambos con una realidad social. De hecho, la per cepción social del valle de Valdivielso, entendido como un "hinterland" rural bajo control de una clase señorial (señores de behetría, los Manrique, San Salvador de Oña), es decir, la creación de un espacio social, debe datarse ya en época feudal. Son elementos típicamente feudales los que dotan de unidad social al espacio geográfico, hasta convertirlo en un espacio social definido.

¿No existió entonces una "comunidad de valle"? Como tal, no. Sí pudo ser un "hinterland" ganadero, o mejor, un espacio utilizado ocasionalmente, dentro de un sistema económico basado en la ganadería extensiva, que se componía, entre otros elementos, de paisajes subordinados coincidentes con valles. En ellos se da un poblamiento inestable, sin apenas asentamientos de carácter sedentario, ocupados de forma extensiva ${ }^{102}$. Se debe tener en cuenta que la débil territorialidad de la sociedad gentilicia posibilitaba este tipo de áreas escasamente habitadas. En realidad, el "valle» tiene una importancia secundaria frente al impulso de las aldeas, y entendido desde la perspectiva que propongo, carece de operatividad explicativa ante la necesidad de análisis de los procesos de génesis, consolidación y transformación de las aldeas, de los que tan sólo es en el mejor de los casos una mera condición de partida ${ }^{103}$. El caso de Valdivielso es muy elocuente al respecto y, como se ha dicho con anterioridad, participa de esos rasgos que vengo reconociendo como de "valle» muy mediatizado. Por decirlo de otra forma, lo importante es la aldea y ésta supone una ruptura total con cualquier tipo de valle, inclusive si éste se define de una forma muy matizada. Se trata de un shinterland" apto para la colonización, en el que no se encuentran obstáculos o vestigios del pasado, como sucede en el hábitat castral.

Podría ser consecuencia todo ello de la desaparición o adaptación al sistema feudal ${ }^{104}$. No obstante, se plantean serias dudas sobre ambas soluciones. En el caso de una adaptación, quedarían rasgos de aquella época comunal,

102 Vid. Laliena Corbera, Carlos, «La formación de la sociedad cristiana en el Pirineo Central aragonés en los siglos VIII-IX): SĖNAC, Philippe (ed.), Frontières et espaces pyrénéens au Moyen Age, Perpignan, 1992, pág. 73, quien opina que las «comunidades de valle» utilizaban como factor aglutinador no tanto el parentesco extenso como la ocupación del espacio, es decir que el aprovechamiento económico, de tipo ganadero, dotaba de mayor coherencia al «valle» y no la organización interna del grupo. De todas formas, su aportación se inscribe en una propuesta de análisis del periodo altomedieval aragonés que subraya el papel de la "gran propiedad» y niega la existencia de un fuerte contenido gentilicio entre los grupos indígenas;

103 Así le sucede a Díez Herrera, Carmen, op. cit., págs. 77-21l, en un apartado significativamente llamado «La cristalización de la aldea», es decir que tiene que recurrir a la aldea para expljcar los procesos de feudalización, aunque parta de los valles. En definitiva, los valles están «curiosamente» formados por un entramado aldeano.

104 Vid. Garcia de CoRTÁzar, José Ángel, «Organización social del espacio...», págs, 223-224. 
pero, en cambio, no poseemos dato alguno que permita corroborarlo, al menos, si hablamos de una "comunidad de valle" en su sentido más amplio. Por el contrario, postular su desarticulación es un ejercicio complicado puesto que la operatividad del valle, como elemento de explicación, queda en entredicho (no se necesita hablar de un supuesto valle que no aporta nada) y más bien parece un silogismo abstracto. En definitiva, lo importante es comprender el proceso de "aldeanización", y desde esa perspectiva abordar la realidad de los "valles" como una condición inicial muy flexible. Además, la ocupación extensiva del espacio por parte de los grupos gentilicios propició la existencia de numerosos territorios escasamente explotados y prácticamente deshabitados, que podían convivir sin problemas dentro del sistema. Así, por ejemplo, los castros no ocupaban necesariamente todo el territorio; su «territorialidad" era diferente a la que se implanta con la lógica feudal o a nuestra lógica.

Por lo tanto, redefinamos el «valle», desde la premisa de una, al menos, duda razonable acerca de la existencia real de «comunidades de valle». Su característica principal era el carácter de espacio subordinado, poco colonizado, e incluso marginal, lo que le convirtió en objeto de atención preferente en la colonización. La escasez de recursos humanos en estas fases colonizadoras, producto en muchos casos de la carencia de puntos de asentamiento articulados y de la pérdida de los lazos gentilicios, hizo necesario el establecimiento de relaciones entre las entidades de población que pudieron pervivir largo tiempo. La permanencia de aspectos comunitarios, sobre todo en lo que respecta al disfrute de pastos, puede ser vestigio elocuente de un pasado prefeudal, pero no necesariamente se explica o se articula en torno a una "comunidad de valle" primitiva que resiste los embates del feudalismo.

Pero, debo repetir que el valle de Valdivielso, el ejemplo que he utilizado, sólo se entiende como valle compuesto por aldeas que dotan de unidad al espacio en períodos posteriores. Como dice el título de este trabajo, es una creación feudal. No es una excepción en cuanto a los valles de alrededor: Valderredible, Tobalina (ambos con grandes influjos del hábitat rupestre), Mena, Espinosa (donde la actividad ganadera será determinante), Valdegovía, etcétera. Mención especial merece el valle de Manzanedo, puesto que se conoce la presencia de castros, lo cual hace necesario un estudio cuidadoso, ya que bien puede tratarse de un área de hábitat castral. No es mi objetivo ser ahora exhaustivo en cada caso, puesto que llevaría a una monografía y presentan además rasgos comarcales específicos que deben ser entendidos desde una perspectiva regional. Tampoco niego que pudieran quizás poseer alguna entidad previamente a la implantación del sistema feudal, pero como áreas subordinadas dentro de un esquema general más amplio, sin desarrollar formas especificas. En todo caso, lo que deseo poner de manifiesto es que estos valles, usados para reforzar el paradigma de las "comunidades de valle», no funcionan como tales. En realidad, no sabemos si son elementos no feudales, puesto que sólo conocemos su existencia dentro del sistema feudal y participando en él. Los datos que poseemos, sobre determinadas prácticas comunitarias no

Hispania, LVII/2, núm. 196 (1997) 679-707 
son suficientes para elaborar un modelo retrospectivo verdaderamente fiable, en especial cuando éstas se documentan en períodos tan tardíos como el siglo xv o la Edad Moderna; utilizar tales referencias para enlazar con realidades de hace 400 o 500 años representa un ejercicio muy peligroso, sobre todo ante los importantes cambios que se producen en otras zonas que no son «valles». Tal supervivencia es cuanto menos sospechosa y tiende a representar la historia de estas comarcas como una "larga duración" inamovible, frente al dinamismo de otras áreas.

Por otro lado, y ya acercándonos al ámbito cantábrico, el valle debe ser reinterpretado, porque puede haberse sobrestimado su peso e influencia respecto de otros sistemas como fueron los castros, algunos de los cuales llegaron a formar concejos en la Edad Media ${ }^{105}$. No cabe duda de que estos teritorios presentan una complejidad social peculiar, una de cuyas manifestaciones más llamativas es la eclosión de un tipo de nobleza local particular. Pero ¿fueron simples "valles" del tipo que propongo o hubo una organización de mayor importancia?

Mi hipótesis es que las zonas marginales dentro del sistema feudal (Fornela, Ancares, Baztán, Vizcaya) presentan determinados rasgos superficialmente arcaizantes. Las aldeas son pequeñas, con una capacidad económica de generar recursos muy escasa, lo que concede un gran papel a las actividades ganaderas y a la recolección simple. Se mantienen ciertas tradiciones comunales, aplicadas a un marco geográfico muy nítido y aislado, relacionadas con operaciones de apoyo mutuo entre aldeas, ante las dificultades que ofrece este paisaje. Pero, son "valles» feudales articulados en torno a aldeas sujetas a señorio a veces diverso. Constituyen una periferia con rasgos comunitarios, no sabemos si de época anterior, dentro de un marco aldeano-feudal. Su mantenimiento se debe en parte a la ausencia de núcleos jerarquizadores con una actividad fuerte, capaces de vertebrar una relación de subordinación firme del territorio, haciéndose necesario recurrir a pactos que generan zonas comunales y acciones de carácter comunitario.

También hay que analizar la conexión entre estos «valles» y la organización castral. En el caso de Sanabria (Zamora) que yo analicé ${ }^{106}$, existió un valle, mero espacio subsidiario, bajo control de un posible centro castral: Puebla de Sanabria. La nitidez del espacio favoreció su identificación y su control por parte de la aristocracia castral, elementos que evolucionarán hasta la creación de un concejo propio, pasando por un "concilium Senabrie», una élite feudal heredera de la aristocracia gentilicia. Comprendiendo el valle desde esta perspectiva menos rígida, se podría aceptar su persistencia en zonas de la submeseta norte, articulándolos con otras estrategias de

lo5 Es el caso del concejo de Camesa o Camesa Castro, documentado para el año 1022. Vid. BOHIGAS ROLDÁN, Ramón, Yacimientos arqueológicos medievales del sector central de la montaña cantábrica, Santander, 1986, vol. I, pág. 157. Toda el área de la actual Cantabria se encuentra jalonada por castros, algunos de los cuales sobreviven en la Alta Edad Media.

106 Vid. MarTín Viso, lîaki, «La feudalización del yalle de Sanabria», en especial págs. 39 y ss. 
ocupación y organización del espacio, incluyendo áreas supuestamente deshabitadas.

En definitiva, es la sociedad la que crea y da contenido al espacio, por lo que no se debe hablar de unidades que se comportan sin cambios aparentes, sino que hay una evolución paralela a los cambios sociales. El valle recibe un contenido sustancialmente diferente en el feudalismo (marco de aldeas $y$ señoríos) que en épocas prefeudales. Como escribía recientemente A. Barrios: «El espacio se interpreta (...) como un resultado inevitable de un proceso de construcción social y de formas de poder, que se desarrolla necesariamente en un delimitado espacio físico y geográfico, durante un determinado período del pasado humano» ${ }^{107}$.

107 «Poder y espacio social: reajustes del poblamiento y reordenación del espacio extremadurano en los siglos xuli-xvm: Despoblación y colonización del valle del Duero. Siglos v|נ1-xx. IV Congreso de Estudios Medievales, León, d995, pág. 233.

Hispuntit, LVII/2, núm. 196 (1997) 679-707 


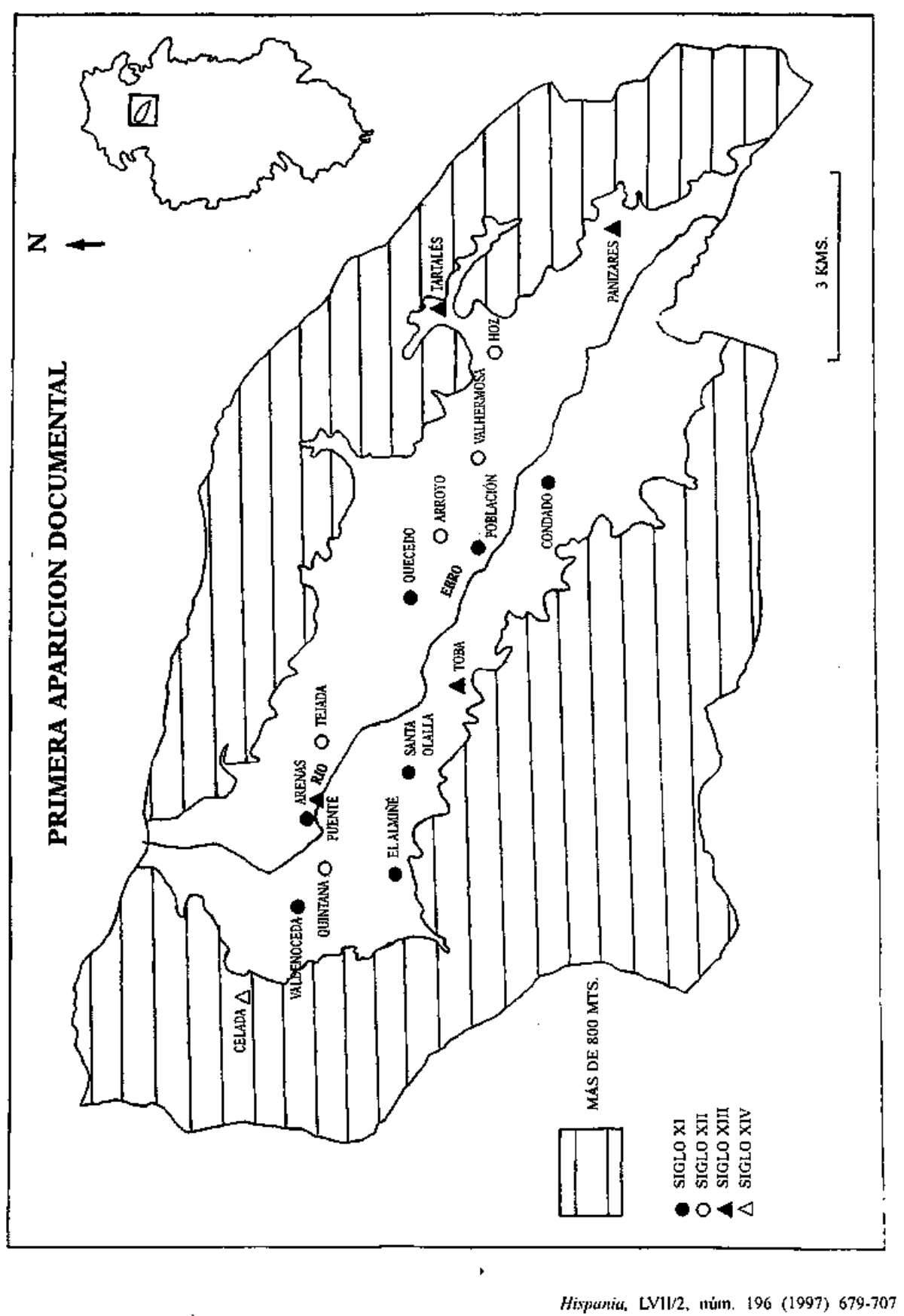

